\title{
A pink colored dioxobilin-type phyllobilin from breakdown of chlorophyll
}

\author{
Chengjie $\mathrm{Li}^{1,2} \cdot$ Bernhard Kräutler $^{1}$ (i)
}

Received: 16 January 2019 / Accepted: 11 February 2019 / Published online: 29 April 2019

(c) The Author(s) 2019

\begin{abstract}
In senescent leaves of higher plants, colorless chlorophyll (Chl) catabolites typically accumulate that belong to one of two major types, classified as formyloxobilin-type or dioxobilin-type phyllobilins (PBs). Natural yellow and pink colored formyloxobilin-type PBs are also known, named YCCs and PiCCs, respectively. A dioxobilin-type yellow Chl catabolite (DYCC) was recently prepared by partial synthesis, characterized by spectroscopic means and also identified in grapevine leaves. Here, we report the first dioxobilin-type pink Chl catabolite (DPiCC) from its partial synthesis from the DYCC. The DPiCC had similar structural features and absorption characteristics (in the visible spectral region) as the natural PiCC, its formyloxobilin-type analogon. In contrast to the effectively racemic PiCC, the DPiCC is an optically active pigment with a stable new asymmetric carbon center.
\end{abstract}

\section{Graphical abstract}

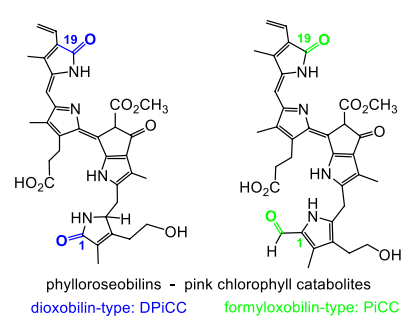

Keywords Heterocycle $\cdot$ Natural product $\cdot$ Pigment $\cdot$ Porphyrins $\cdot$ Linear tetrapyrroles

\section{Introduction}

Dedicated to Professor Heinz Falk on the occasion of his 80th birthday.

Electronic supplementary material The online version of this article (https://doi.org/10.1007/s00706-019-02396-5) contains supplementary material, which is available to authorized users.

Bernhard Kräutler

bernhard.kraeutler@uibk.ac.at

1 Institute of Organic Chemistry and Centre of Molecular Biosciences, University of Innsbruck, Innrain 80/82, 6020 Innsbruck, Austria

2 Present Address: Key Laboratory for Advanced Materials and Institute of Fine Chemicals, School of Chemistry and Molecular Engineering, East China University of Science and Technology, Meilong Rd 130, Shanghai 200237, China
The disappearance of chlorophyll (Chl) in fall leaves and the concomitant development of fall colors have been a fascinating puzzle, unsolved until about 30 years ago [1-3]. Bilin-type Chl catabolites have been discovered and studied in higher plants, classified as phyllobilins (PBs) $[4,5]$. Colorless PBs accumulate in senescent leaves as products of the largely common 'PAO/phyllobilin' pathway of Chl breakdown [6-8]. They derive from a 'red Chl catabolite' (RCC) [9-11], the cryptic red formyloxobilin that results from specific oxygenolysis of the macrocycle of pheophorbide $a$ (Pheide $a$ ) by Pheide $a$ oxygenase (PAO), as the common progenitor of the PBs (see Fig. 1) [12, 13]. Enzymatic reduction of RCC by RCC reductases (RCCRs) [7, 8, 14-17] produces blue fluorescent formyloxobilins, named 'primary 
Fig. 1 Structural outline of key steps of the $\mathrm{PAO} /$ phyllobilin pathway of Chl breakdown. Oxygenolysis of Pheide $a$ with PAO furnishes the red bilintype tetrapyrrole RCC, which is reduced to one of the two C16-epimeric 'primary' FCCs ( $p$ FCCs). Further metabolism of $p$ FCCs produces two major types of colorless 'nonfluorescent' phyllobilins (PBs), either 1-formyl-19-oxobilanes (NCCs) or 1,19-dioxobilanes (DNCCs), also classified as type-I or typeII $\mathrm{PBs}$, respectively
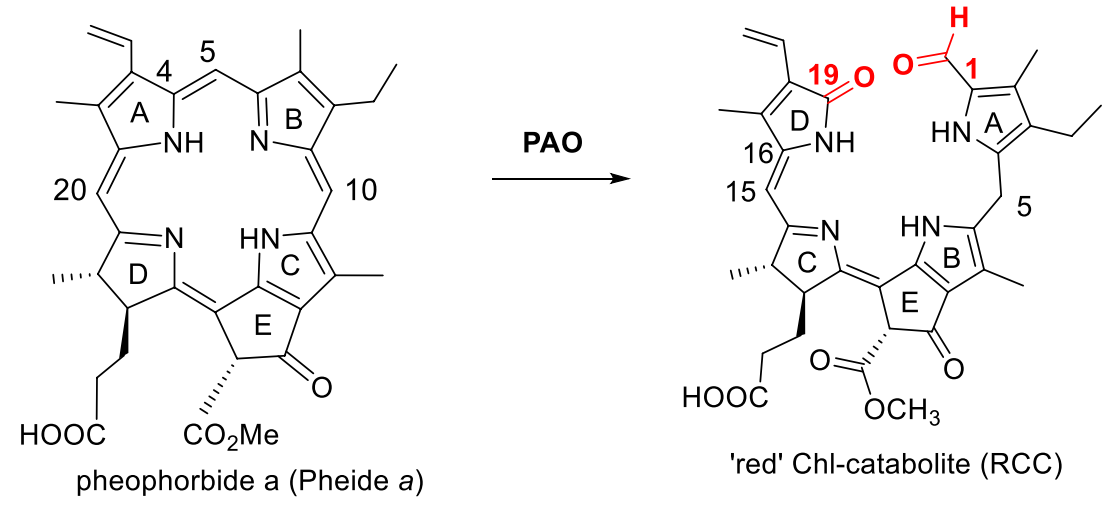

'red' Chl-catabolite (RCC)

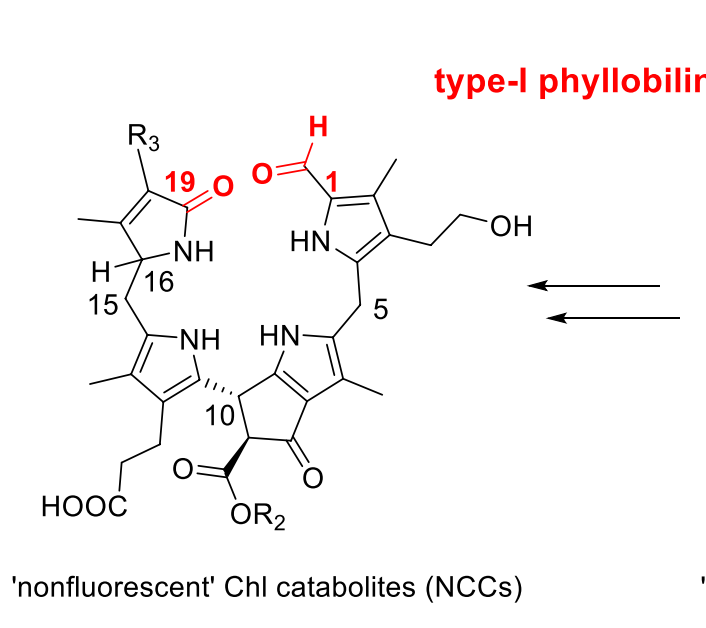

$\downarrow$ RCCR

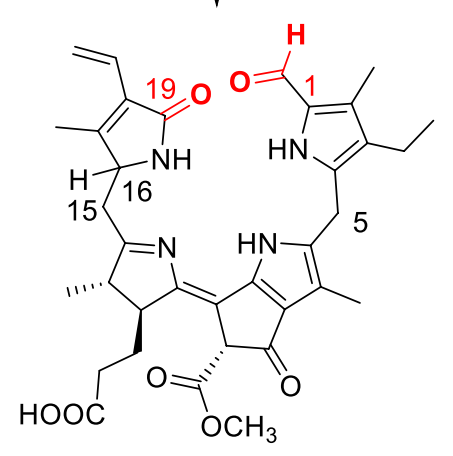

'primary 'fluorescent' Chl catabolites (pFCCs)

type-II phyllobilins

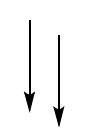

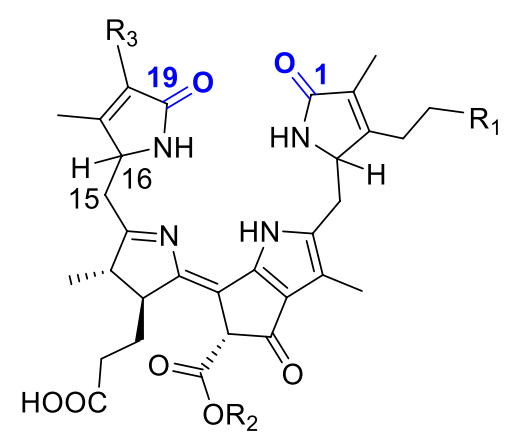

dioxobilin-type FCCs (DFCCs) fluorescent' Chl catabolites ( $p$ FCCs) $[18,19]$, from which a variety of fluorescent Chl catabolites (FCCs) are generated by further modifications by the action of chloroplastic or cytosolic enzymes [5, 8, 20,21]. The typical FCCs are only fleetingly existent and isomerize rapidly in a weakly acidic aqueous environment to corresponding formyloxobilintype 'nonfluorescent' Chl catabolites (NCCs) [22, 23]. A competitive oxidative FCC deformylation by a cytochrome P450 type enzyme (identified as CYP89A9 in Arabidopsis thaliana) leads to corresponding dioxobilin-type fluorescent
Chl catabolites (dioxobilin-type FCCs or DFCCs) [24, 25]. As do FCCs, DFCCs also isomerize stereo-selectively, furnishing their nonfluorescent isomers, dioxobilin type NCCs (DNCCs) [25]. DNCCs, detected as apparently exotic 'urobilinogenoidic' Chl catabolites [26], have meanwhile been shown to be abundant in a variety of leaves and fruit $[5,21$, 27-29]. Thus, two major lines of colorless, 'nonfluorescent' Chl catabolites are known to accumulate in senescent leaves of angiosperms, representing either NCCs (type-I phyllobilanes) or DNCCs (type-II phyllobilanes) [4, 5]. Yellow 
descendants of NCCs, yellow (formyloxobilin-type) Chl catabolites (YCCs) [30, 31] and analogous pink colored $\mathrm{Chl}$ catabolites (PiCCs) [32] have been discovered in extracts of senescent leaves and their structures and reactivity have been investigated [5, 33].

The dioxobilin-type NCCs, named DNCCs [5, 21, 24], have been observed recently in some leaves (and leaf extracts), to be oxidized regio-selectively, similar to NCCs, generating dioxobilin-type yellow Chl catabolites (DYCCs) [34]. Furthermore, the availability of the semisynthetic DYCC 1 (a type-II phylloxanthobilin) invited the exploration of a partial synthesis of its pink colored analog, the DPiCC 2, a type-II phylloroseobilin (PrB). As shown here, the DYCC 1 did undergo air oxidation readily and selectively, in particular in the presence of $\mathrm{Zn}$ (II)-ions, providing the DPiCC 2 (a 1,19-dioxo-1,4,16,19-tetrahydro-phyllobiladiene- $b, c$, according to the semi-systematic phyllobilin nomenclature [4]) and a first representative of the optically active class of the pink colored type-II PrBs.

\section{Results and discussion}

For the partial synthesis of DPiCC 2 from DYCC 1 (Fig. 2), we used the method developed for the preparation of the PiCC 3 from YCC [33, 35] via an intermediate blue Zn-complex. When a solution of $7.2 \mathrm{mg}$ of DYCC 1 (prepared from
$V v$-DNCC-51 [21]) [34] in DMF was treated with an excess of $\mathrm{Zn}(\mathrm{OAc})_{2}$ at room temperature and in the presence of $\mathrm{O}_{2}$, the color of the reaction mixture changed slowly from yellow to blue. After $18 \mathrm{~h}$, a TLC showed complete disappearance of the DYCC 1 and the blue reaction mixture was worked up (Experimental Section). To the solution of the blue residue (tentatively, the $\mathrm{Zn}$-complex of DPiCC) in $\mathrm{MeCN}$, an acidic potassium phosphate buffer was added, leading to a rapid color change of the solution to red, due to the formation of the metal-free DPiCC 2 . Upon purification by desalting on a Sep-Pak Cartridge, $6.6 \mathrm{mg}$ of $\mathbf{2}$ (92\% yield) was isolated as a dark red powder, which was characterized directly by a set of UV/Vis, CD, mass and NMR spectra.

In the absorption spectra of both DPiCC 2 and PiCC 3 [33] in $\mathrm{MeOH}$, the common PrB-chromophore dominated the absorption at long wavelengths (Fig. 3, top). The long wavelength absorption band of both $\operatorname{PrBs}(2$ and 3) featured an intense peak with a maximum at $522 \mathrm{~nm}$, accompanied by a shoulder near $485 \mathrm{~nm}$. The extension of the $\pi$-system, from two pyrrolic rings in the DYCC 1 to three pyrrolic rings in DPiCC 2, leads to a bathochromic shift of about $100 \mathrm{~nm}$ (to $522 \mathrm{~nm}$ ) [21, 34]. As was the case for DYCCs, the ring A lactam structure of DPiCC 2, instead of a formyl pyrrole unit in PiCC 3, diminished the absorbance near $320 \mathrm{~nm}$, and two less intense maxima at 315 and $338 \mathrm{~nm}$ are observed in the spectrum of 2 . The $\mathrm{CD}$ spectrum of the (racemic) PiCC 3 in $\mathrm{MeOH}$ was
Fig. 2 Left and center: Structural outline of a partial synthesis of the dioxobilin-type pink Chl catabolite DPiCC 2 by air oxidation of the DYCC 1 via a blue intermediate $\mathrm{Zn}$ complex. DYCC 1 is available from oxidation of the natural $V v$-DNCC-51 [34]. Right: The structural formula of the formyloxobilin-type pink $\mathrm{Chl}$ catabolite PiCC $\mathbf{3}$ is shown for comparison
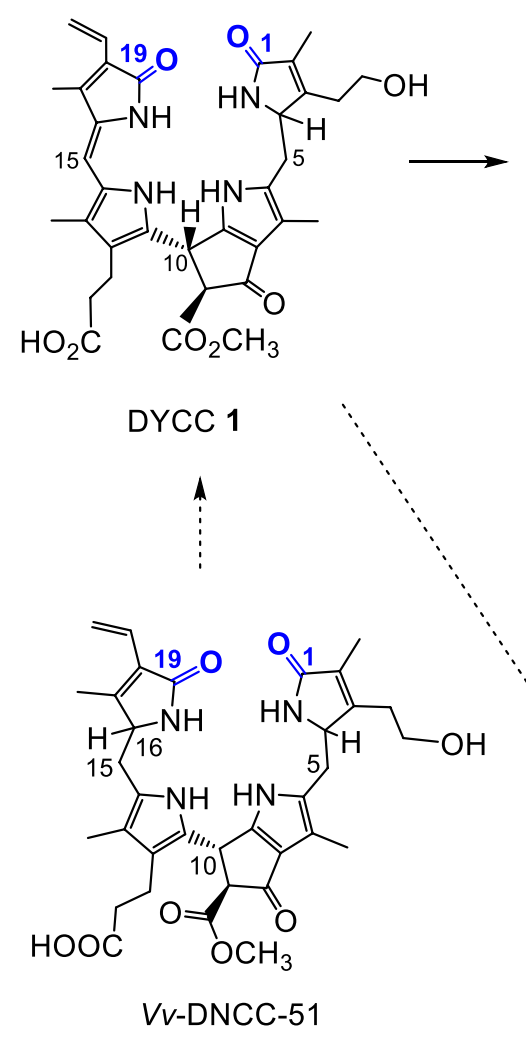

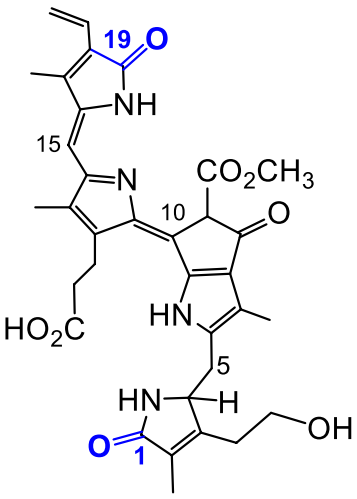

DPiCC 2
$\operatorname{PiCC} 3$

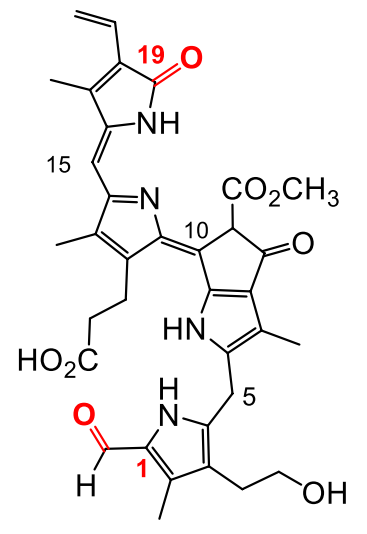



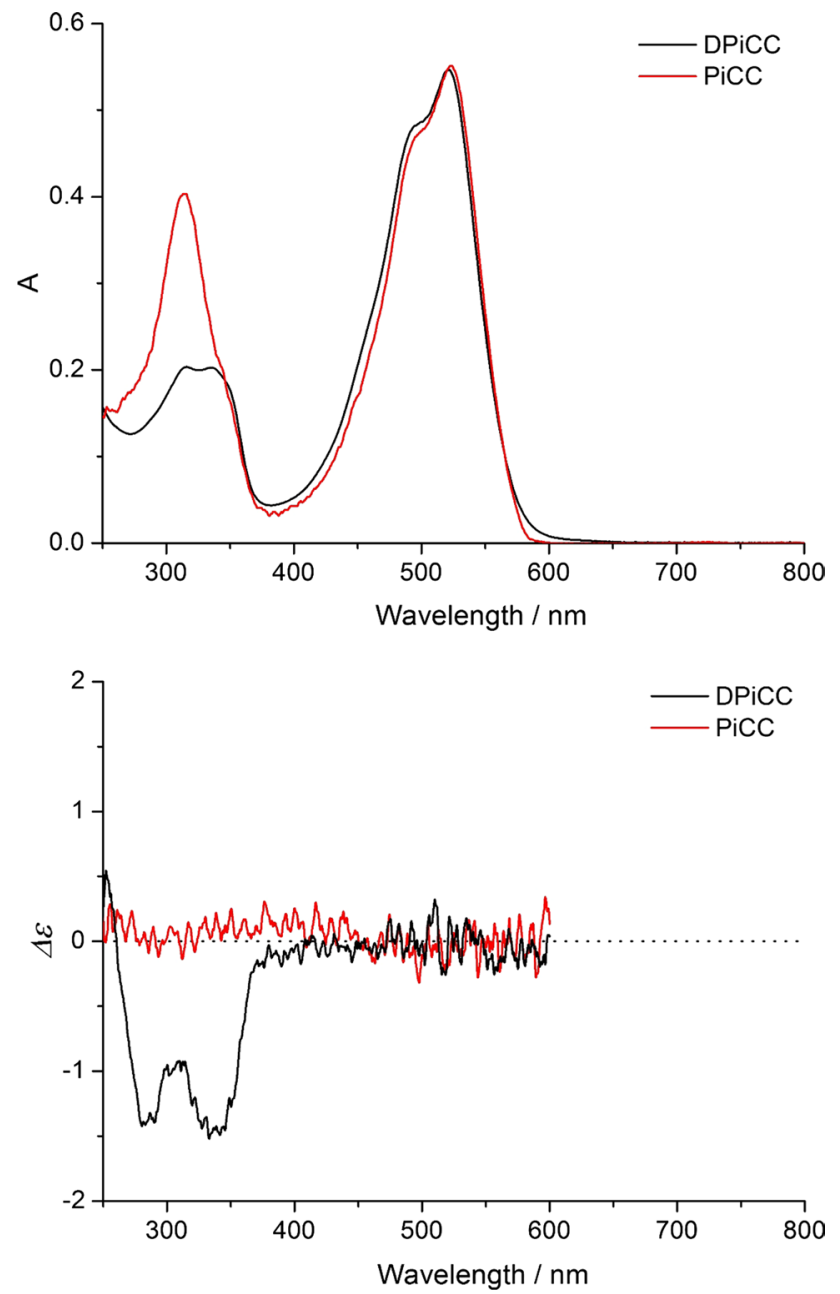

Fig. 3 Top: UV/Vis spectra of DPiCC 2 and PiCC 3 in $\mathrm{MeOH}$ $\left(1.53 \times 10^{-5} \mathrm{~mol} \mathrm{dm}^{-3}\right)$; Bottom: CD spectra of DPiCC 2 and PiCC 3 in $\mathrm{MeOH}\left(3.1 \times 10^{-5} \mathrm{~mol} \mathrm{dm}^{-3}\right)$

featureless, but a pronounced and structured CD spectrum was observed for the solution of the DPiCC 2 (Fig. 3, bottom). Solutions of $\mathbf{2}$ in $\mathrm{MeOH}$ show a weak cotton effect at $336 \mathrm{~nm}$ and $285 \mathrm{~nm}$, consistent with the stable configuration of the asymmetric methine $\mathrm{HC} 4$. The configuration of $\mathrm{C} 4$ of $\mathbf{2}$ was tentatively assigned as $R$, as it is inherited intact from the type-II precursors DYCC 1 [34] and $V v$ DNCC-51 [21].

The molecular formula of DPiCC 2 was deduced as $\mathrm{C}_{34} \mathrm{H}_{36} \mathrm{~N}_{4} \mathrm{O}_{8}$, from its ESI-MS spectrum that exhibited strong pseudo-molecular ions at $m / z=689.1[\mathrm{M}-\mathrm{H}+\mathrm{Na}+\mathrm{K}]^{+}$, at $m / z=667.1[\mathrm{M}+\mathrm{K}]^{+}$, and at $m / z=651.4[\mathrm{M}+\mathrm{Na}]^{+}$(Fig. S5a-S5c), confirming the (formal) loss of one $\mathrm{C}$, when going from the (formyloxobilin-type) PiCC 3 to the (dioxobilintype) DPiCC 2.

In a $500 \mathrm{MHz}{ }^{1} \mathrm{H}$ NMR spectrum of 2 in $\mathrm{CD}_{3} \mathrm{OD}$, the signals of 30 non-exchangeable protons were observed (Fig. 4). The structure of $\mathbf{2}$ was established by correlations in twodimensional ${ }^{1} \mathrm{H},{ }^{1} \mathrm{H}$-COSY, ${ }^{1} \mathrm{H},{ }^{1} \mathrm{H}$-ROESY, ${ }^{1} \mathrm{H},{ }^{13} \mathrm{C}$-HSQC, and ${ }^{1} \mathrm{H},{ }^{13} \mathrm{C}$-HMBC spectra. The signal pattern of a vinyl group and a singlet (vinyl HC15) was observed at intermediate field. The four $\mathrm{H}_{3} \mathrm{C}$ groups of $\mathbf{2}$ were observed at high field as three (apparent) singlets and a pair of similarly intense singlets at 1.71 and $1.79 \mathrm{ppm}\left(\right.$ of $\left.\mathrm{H}_{3} \mathrm{C} 2^{1}\right)$, consistent with the presence of two similarly important $\mathrm{C}^{2}$-epimers. The partially saturated lactam unit in $\mathbf{2}$ leads to a new spin system $\mathrm{ABX}$ of the $\mathrm{H}_{2} \mathrm{C} 5$-HC4 section (in $3 \mathrm{H}_{2} \mathrm{C} 5$ produced an AB system) (Fig. S2). A complex AB-type system at $2.79 \mathrm{ppm}\left(\mathrm{H}_{\mathrm{A}}\right)$ and $3.40 \mathrm{ppm}\left(\mathrm{H}_{\mathrm{B}}\right)$ correlated with a carbon with resonance at $29.6 \mathrm{ppm}$ in HSQC spectrum and was assigned to the methylene group $\mathrm{H}_{2} \mathrm{C} 5$. In addition, $\mathrm{H}_{\mathrm{A}}$ and $\mathrm{H}_{\mathrm{B}}$ coupled with a signal at $4.59 \mathrm{ppm}\left(J_{\mathrm{AX}}=8.9 \mathrm{~Hz}\right.$, $J_{\mathrm{BX}}=4.6 \mathrm{~Hz}$ ), which was assigned to the asymmetric $\mathrm{HC} 4$. Two ${ }^{1} \mathrm{H},{ }^{1} \mathrm{H}$-ROESY-correlations with similar strengths from $\mathrm{HC} 15$ to $\mathrm{H}_{3} \mathrm{C} 17^{1}$ and to $\mathrm{H}_{3} \mathrm{C} 13^{1}$ indicated the $\mathrm{Z}$-configuration of the $\mathrm{C} 15=\mathrm{C} 16$ bond. However, as the signals of all $\mathrm{HNs}$ and of $\mathrm{C}^{2}$ were lacking in the spectrum in $\mathrm{CD}_{3} \mathrm{OD}$, the configuration at the $\mathrm{C} 10=\mathrm{C} 11$ bond could not be deduced.

To find the signals of exchange-labile protons, DMSO$d_{6}$ and $\mathrm{CD}_{3} \mathrm{CN}$ were employed as alternative solvents for NMR analyses (Figs. 5, S4 and Table S1). In both solvents, two more NHs' signals were observed at low field. In the spectrum of 2 in DMSO- $d_{6}$, a signal at $10 \mathrm{ppm}$ was assigned to $\mathrm{HN} 24$ of ring $\mathrm{D}$, owing to its correlations in a ${ }^{1} \mathrm{H},{ }^{13} \mathrm{C}-$ HMBC spectrum to the carbons at ring D. In the ${ }^{1} \mathrm{H},{ }^{1} \mathrm{H}-$ ROESY spectrum HN24 also coupled with the methyl ester signal at $3.64 \mathrm{ppm}$ and with $\mathrm{HC}^{2}$ at $5.05 \mathrm{ppm}$, indicative

Fig. $4500 \mathrm{MHz}{ }^{1} \mathrm{H}$ NMR spectrum of DPiCC 2 in $\mathrm{CD}_{3} \mathrm{OD}$ $\left(25^{\circ} \mathrm{C}, 3.5 \times 10^{-3} \mathrm{~mol} \mathrm{dm}^{-3}\right)$

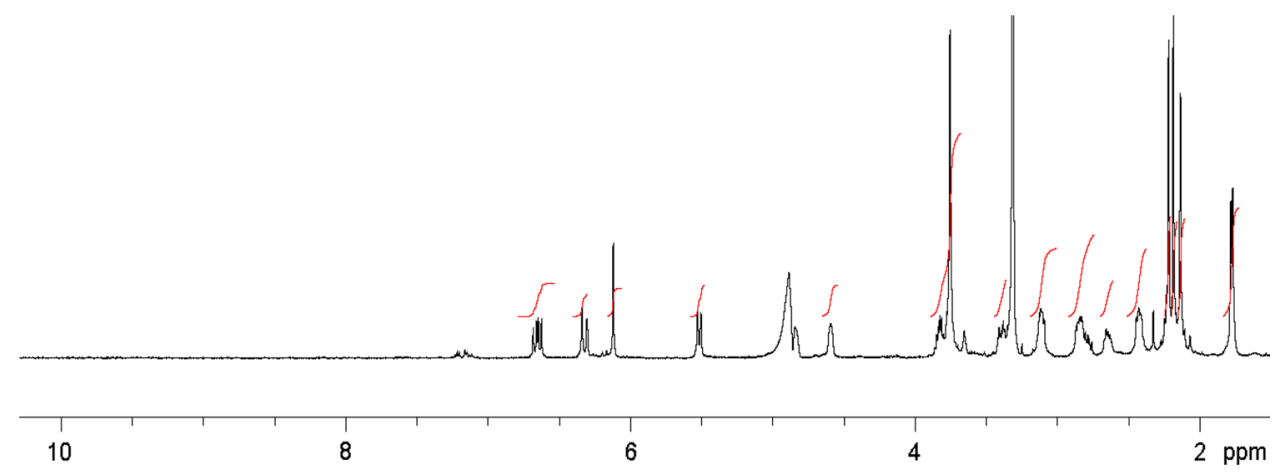


Fig. 5 NMR chemical shift data of DPiCC 2 (500 MHz NMR,

$25{ }^{\circ} \mathrm{C}$ ) depicted in a graphical representation of the derived molecular structure (top: spectrum in $\mathrm{CD}_{3} \mathrm{OD}$; bottom: spectrum in DMSO- $d_{6}$ ) Left: Homonuclear correlations from ${ }^{1} \mathrm{H},{ }^{1} \mathrm{H}$-ROESY experiments (arrows; bold bonds represent spin systems derived from ${ }^{1} \mathrm{H},{ }^{1} \mathrm{H}-\mathrm{COSY}$ spectra). Right: Heteronuclear correlations and signal assignments obtained from ${ }^{1} \mathrm{H},{ }^{13} \mathrm{C}$-HSQC spectra (shaded boxes) and ${ }^{1} \mathrm{H},{ }^{13} \mathrm{C}$ HMBC experiments (arrows). Dashed arrows indicate weak couplings
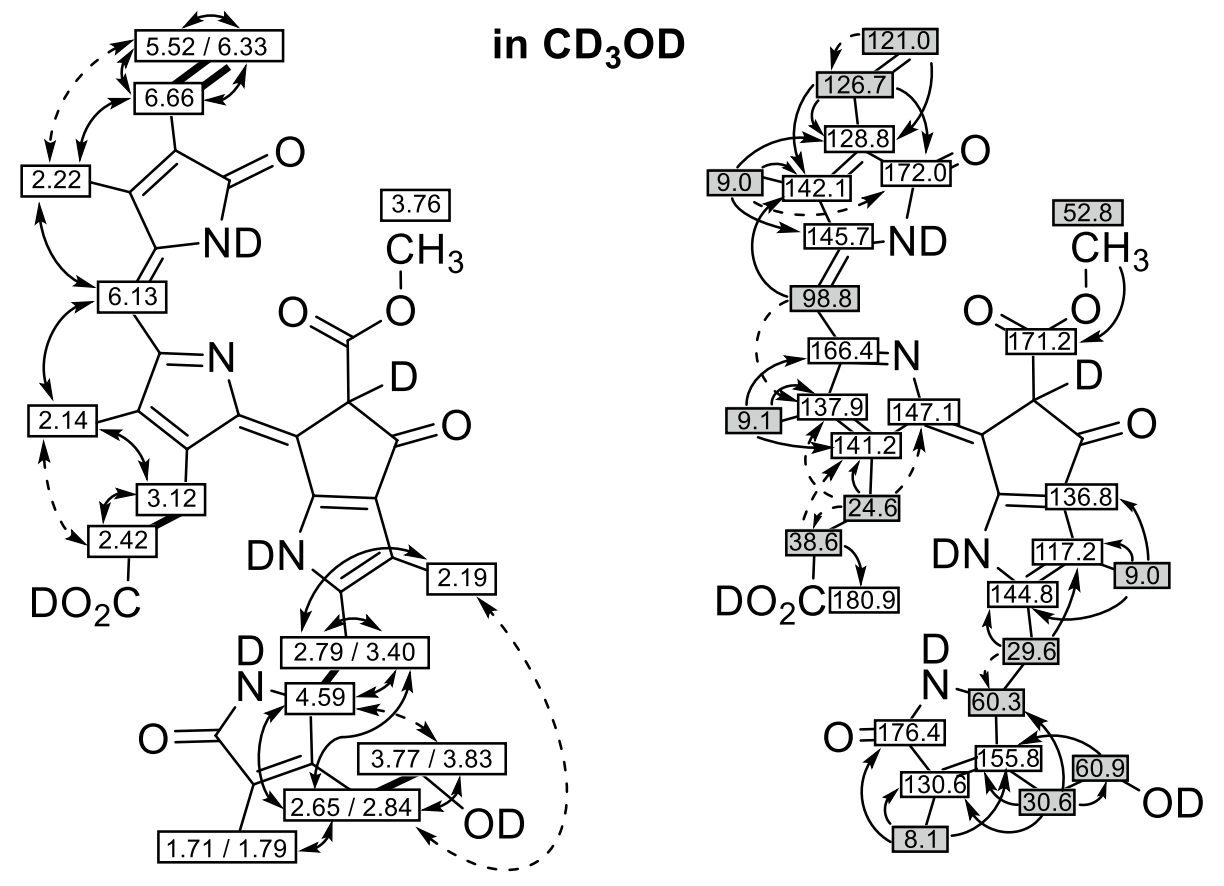

in DMSO-d 6

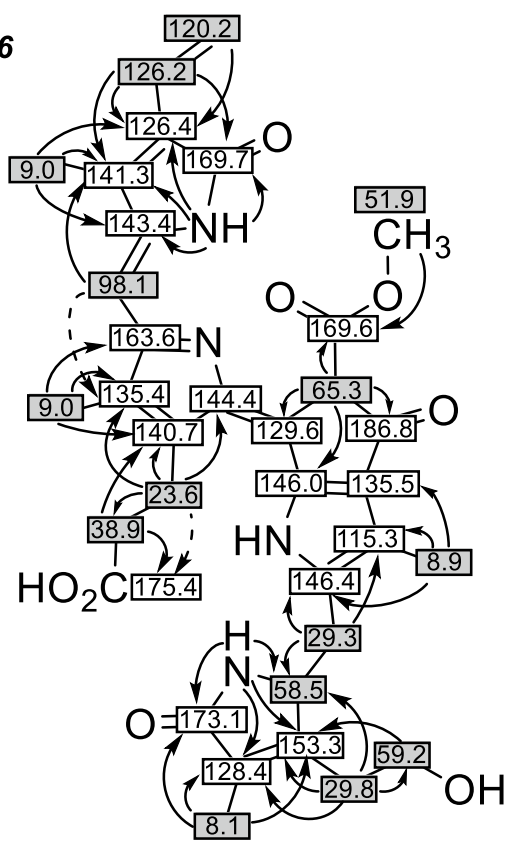

of $E$-configuration of the $\mathrm{C} 10=\mathrm{C} 11$ double bond, as first deduced for the type-I analog PiCC 3 [32, 35].

Interestingly, an $\mathrm{NH}$ signal around $8.1 \mathrm{ppm}$, which correlated with $\mathrm{HC} 4$ at $4.37 \mathrm{ppm}$, was split into two singlets and could be assigned to $\mathrm{HN} 21$ of ring A. The signals of the two NHs', of $\mathrm{HC}^{2}, \mathrm{H}_{3} \mathrm{C} 2^{1}$ and $\mathrm{H}_{3} \mathrm{C} 7^{1}$ in DMSO- $d_{6}$ were, likewise, split into two, indicating the existence of $\mathbf{2}$ in two nearly equally populated diastereo-isomers. The deduced structure indicates two asymmetric carbon centers in a molecule of the DPiCC 2, one of which (at $\mathrm{C} 8^{2}$ ) undergoes epimerization readily, as was observed for PiCC 3 [33]. The stable configuration at $\mathrm{C} 4$ of DYCC 1 , provisionally deduced as $R$, and the deduced presence of both DPiCC $8^{2}$-epimers (probably as $4 R, 8^{2} R$ - and $4 R, 8^{2} S$-epimers) gave rise to the two sets of signals.

In $\mathrm{CD}_{3} \mathrm{CN}$, the signals of the two $\mathrm{NHs}$, of $\mathrm{H}_{3} \mathrm{C}^{1}$ and of $\mathrm{HC} 8^{2}$ of 2 also split into two singlets with approximately equal intensity. In the ${ }^{1} \mathrm{H},{ }^{1} \mathrm{H}$-ROESY spectrum of $\mathbf{2}$ in $\mathrm{CD}_{3} \mathrm{CN}$, significant correlations of $\mathrm{HN} 21$ (at $6.84 \mathrm{ppm}$ ) to $\mathrm{HC} 4$ (at $4.55 \mathrm{ppm}$ ) were observed. The signal of HN21 of 
2 underwent a large solvent-induced shift to lower field in DMSO- $d_{6}$, when compared to $\mathrm{CD}_{3} \mathrm{CN}$. This difference may be due to the presence of an H-bond between HN21 of 2 and DMSO, and its absence in $\mathrm{CD}_{3} \mathrm{CN}$. The remaining proton signals of $\mathbf{2}$ featured similar chemical shifts in both solvents. Except for the protons at their ring A, the signals of DPiCC 2 and PiCC 3 occurred at very similar chemical shift in ${ }^{1} \mathrm{H}$ NMR spectra taken in DMSO- $d_{6}$ (Fig. S3 and Table S1).

As deduced here for DPiCC 2, pink colored type-II phylloroseobilins (PrBs) feature the same chromophore as the type-I analogs (such as PiCC 3) that extends over three conjugated pyrrole rings and displays a $10 E, 15 Z$ double bond configuration. Three $\mathrm{N}$-atoms that are part of the chromophore are ready for coordination to metals, but require a change of the configuration of the $\mathrm{C} 10=\mathrm{C} 11$ double bond to coordinate a metal ion in a tridentate fashion. Indeed, the type-I PrBs undergo the critical double-bond isomerization readily and show remarkable affinity for transition metal ions, such as $\mathrm{Ni}(\mathrm{II}), \mathrm{Cu}(\mathrm{II}), \mathrm{Zn}$ (II), $\mathrm{Cd}(\mathrm{II})$, relevant in the biosphere [33, 35]. Hence, PiCCs (such as 3) are able to signal the presence of transition metals in aqueous solution, by coordinating them in complexes that exhibit characteristically changed colors and fluorescence properties [33]. However, the chiroptical properties of type-I and type-II PrBs differ characteristically, as only the latter (such as DPiCC 2) are inherently optically active due to the stable configuration of its asymmetric C4. Type-II PrBs are, thus, expected to show a pronounced capacity for the chelation of transition metals in complexes that are optically active. The ready availability of the DPiCC $\mathbf{2}$ has meanwhile provided the basis for first studies of the chelation of transition metals by this type-II phylloroseobilin and of the properties of the corresponding metal complexes, a subject to be reported in due course. Indeed, their abilities to coordinate metal ions $[35,36]$ may give phyllochromobilins a role in biological transport, detoxification or activation of transition metals.

The ubiquitous colorless 'nonfluorescent' bilane-type $\mathrm{Chl}$ catabolites are readily oxidized by a still ill-characterized process in leaves (and leaf extracts), furnishing yellow $\mathrm{Chl}$ catabolites (YCCs and DYCCs). These yellow pigments feature the same extended chromophore as available (twice) in the heme-derived bilirubin (BR) and exhibit interesting photochemistry (Z/E photoisomerization [30, 37] and/or $[2+2]$ photo-dimerization $[31,37])$, relating them to BR, as well [38]. Interestingly, the phylloxanthobilins (PxBs) are easily oxidized further to the pink colored phylloroseobilins (PrBs), some of which have also been detected in plant extracts [32]. Possibly, the sequential oxidation to yellow and pink phyllochromobilins represents a route for the further breakdown of $\mathrm{Chl}$ beyond the stage of the bilane-type NCCs and DNCCs [5]. Remarkably, colorless tetrapyrrolic $\mathrm{Chl}$ catabolites in senescent leaves of fern (Pteridium aquilinum) feature a rearranged carbon skeleton at their ring B
[39] that would inhibit their simple oxidation with generation of a type of PrB.

\section{Conclusion}

The unique structural features of phyllobilins, as abundant products of $\mathrm{Chl}$ breakdown, encourage considering their potential roles in nature. In earlier investigations of $\mathrm{Chl}$ breakdown, the then known colorless non-fluorescent $\mathrm{Chl}$ catabolites (NCCs) were suggested to represent the "final" products of a (mere) Chl detoxification process [40, 41]. However, the formation in some leaves and fruit of a variety of specifically 'sugar-decorated' colorless and blue fluorescent phyllobilins [20,21], as well as the natural existence of (brightly colored) phyllochromobilins [5, 42], has invited consideration of the critical physiological effects for the natural PBs. Indeed, the enzymatic transformation of the first formed formyloxobilin-type (or type-I) PBs to 1,19-dioxobilin-type linear tetrapyrroles (the type-II phyllobilins) [24] generates PBs with an even closer general structural similarity to the heme-derived (hemo-) bilins [4, 43], linear tetrapyrroles with a range of crucial functions in life [38, 43]. The structural relationship may be most pronounced with the colored representatives, the (type-II) phyllochromobilins. The chromophore of the pink PrBs is very similar to the one of phycoviolobilin [43] (its protein-bound Cysaddition form basically is a Z/E-isomer of 2) [4] and relates also to other heme-derived linear tetrapyrroles important in biological photo-regulation [44-46]. The structural similarities between members of the two large classes of natural linear tetrapyrroles, as well as the major structural difference remaining (the ring E moiety of the PBs, which is absent in the heme-derived bilins [43]), invite studies of the physiological effects of phyllochromobilins in photosynthesizing organism and animals.

\section{Experimental}

DMF, pyridine, and $\mathrm{CH}_{2} \mathrm{Cl}_{2}$ were reagent-grade commercials and distilled before use. $\mathrm{MeOH}$ (HPLC grade), from VMR (Leuven, Belgium); water, from Millipore S. A. S. Milli-Q Academic system (18.2 $\mathrm{M} \Omega \mathrm{cm}$, Molsheim, France); ACS reagent $\mathrm{KH}_{2} \mathrm{PO}_{4}$ and $\mathrm{K}_{2} \mathrm{HPO}_{4}$ from SigmaAldrich (Steinheim, Germany). Thin-layer chromatography (TLC): Merck $0.25 \mathrm{~mm}$ silicagel 60 plates. SepPak-C18 Cartridges (Silica-based bonded phase with strong hydrophobicity), from Waters Associates (Milford, USA). pH Values, measured with a WTW Sentix 21 electrode, WTW pH535 digital pH meter. DYCC 1 $\left(8^{2} S, 10 R\right)$-1,19-dioxo-1,4,16,19-tetrahydro-phyllobilene- $\left.c\right)$ [34] was obtained by oxidation of $V v$-DNCC-51 $\left(8^{2} S, 10 R\right.$, 
16epi)-1,19-dioxo-1,4,16,19-tetrahydro-phyllobilane), which was isolated from the senescent leaves of grapevine (Vitis vinifera) [21].

UV/Vis: Varian Cary 60 spectrophotometer; $\lambda_{\max }$ in $\mathrm{nm}(\log \varepsilon)$. CD-spectra: JASCO J-715 spectropolarimeter; $\lambda_{\max }$ and $\lambda_{\min }$ in $\mathrm{nm}(\Delta \varepsilon) .{ }^{1} \mathrm{H}$ NMR: Varian UNITY plus $500 ; \delta$ in ppm with $\delta\left(\mathrm{CHD}_{2} \mathrm{OD}\right)=3.31 \mathrm{ppm}, \delta$ $\left(\mathrm{CHD}_{2} \mathrm{CN}\right)=1.94 \mathrm{ppm}, \delta\left(\mathrm{CD}_{3} \mathrm{SOCD}_{2} \mathrm{H}\right)=2.50 \mathrm{ppm}$, coupling constant $J_{\mathrm{HH}}$ in $\mathrm{Hz} ;{ }^{13} \mathrm{C}$ NMR: chemical shift values and signal assignments from ${ }^{1} \mathrm{H},{ }^{13} \mathrm{C}$-HSQC and ${ }^{1} \mathrm{H},{ }^{13} \mathrm{C}$ HMBC spectra. ESI-MS [ $/ \mathrm{m} / \mathrm{z}$ (relative intensity \%)]: Finnigan LCQ Classic, ESI source, positive ion-mode, flow rate $2 \mathrm{~cm}^{3} \mathrm{~min}^{-1}$, solvent water/MeOH.

Gynkotek 480G 'high precision pump' with vacuum online degasser; Gynkotek DA340 diode array detector; Column: Phenomenex ODS-Hyperclone $(5 \mu, 250 \times 4.6 \mathrm{~mm}$ i.d.) protected with pre-column a Phenomenex Security Guard C18 $4 \times 3 \mathrm{~mm}$ i.d.; flow rate: $0.5 \mathrm{~cm}^{3} / \mathrm{min}$; all chromatograms were taken at room temperature $\left(23^{\circ} \mathrm{C}\right)$; solvent $\mathrm{A}$ : $50 \mathrm{mM}$ aq. potassium phosphate ( $\mathrm{pH} 7.0$ ), solvent $\mathrm{B}: \mathrm{MeOH}$, solvent $\mathrm{C}: \mathrm{H}_{2} \mathrm{O}$; solvent composition $(\mathrm{A} / \mathrm{B} / \mathrm{C})$ : $0-5 \mathrm{~min}$ : $60 / 40 / 0 ; 5-15 \mathrm{~min}$ : from $60 / 40 / 0$ to $30 / 70 / 0 ; 15-25 \mathrm{~min}$ : from 30/70/0 to 0/100/0; 25-35 min: 0/100/0; 35-37 min: 0/100/0 to $0 / 90 / 10 ; 37-42 \mathrm{~min}$ : from $0 / 90 / 10$ to $60 / 40 / 0$.

\section{1,19-Dioxo-1,4,16,19-tetrahydrophyllobiladiene- $b, c$} (DPiCC, 2, $\left(\mathrm{C}_{37} \mathrm{H}_{48} \mathrm{~N}_{4} \mathrm{O}_{4}\right)$ To the solution of $7.2 \mathrm{mg}$ DYCC $1(11.5 \mu \mathrm{mol})$ in $4.3 \mathrm{~cm}^{3}$ distilled $N, N$-dimethylformamide (DMF), $10.6 \mathrm{mg} \mathrm{Zn}(\mathrm{OAc})_{2}(57.9 \mu \mathrm{mol}, 5 \mathrm{eq})$ and $0.43 \mathrm{~cm}^{3}$ pyridine were added. The reaction mixture was purged with $\mathrm{O}_{2}$ and stirred at room temperature in the dark for $18 \mathrm{~h}$. The color of the reaction mixture changed slowly from yellow to blue. When no DYCC (yellow spot) was detected on the TLC (silica gel without $\mathrm{F} 254,90 / 10 \mathrm{MeOH} / \mathrm{CHCl}_{3}$ ), the dark blue reaction mixture was diluted with $30 \mathrm{~cm}^{3}$ of $\mathrm{H}_{2} \mathrm{O}$ and extracted with $\mathrm{CH}_{2} \mathrm{Cl}_{2}\left(3 \times 30 \mathrm{~cm}^{3}\right)$. The combined organic phases were filtered through a plug of dry cotton wool and the solvent was evaporated under reduced pressure to give a dark blue residue. The blue residue was re-dissolved in $0.2 \mathrm{~cm}^{3} \mathrm{DMF}$ and diluted with $15 \mathrm{~cm}^{3}$ of MeCN. To this mixture, $30 \mathrm{~cm}^{3}$ of $100 \mathrm{mM} \mathrm{KH}_{2} \mathrm{PO}_{4}(\mathrm{pH} 4.7)$ was added. After $3 \mathrm{~h}$, a red reaction mixture was obtained and extracted with $\mathrm{CH}_{2} \mathrm{Cl}_{2}\left(3 \times 30 \mathrm{~cm}^{3}\right)$. The combined organic phase was dried by filtration through a plug of dry cotton wool and was concentrated under reduced pressure to get the raw product DPiCC 2 as dark red residue. The raw DPiCC 2 was dissolved in $2 \mathrm{~cm}^{3}$ of MeOH and diluted with $3 \mathrm{~cm}^{3}$ of $50 \mathrm{mM}$ potassium phosphate buffer ( $\mathrm{pH}$ 7.0). The solution was loaded on a Sep-Pak-C18 cartridge (5 g). After washing with $20 \mathrm{~cm}^{3} \mathrm{H}_{2} \mathrm{O}$, the red fraction was washed down with $\mathrm{MeOH} /$ $\mathrm{H}_{2} \mathrm{O}(3 / 4, v / v)$. The obtained red fractions were combined and the $\mathrm{MeOH}$ was removed completely under reduced pressure (10 mbar). Then, the solution was frozen in liquid
$\mathrm{N}_{2}$ and lyophilization was employed to get the product. Finally, $6.6 \mathrm{mg}$ of DPiCC 2 was obtained as dark red powder and yield is $92 \%$. UV/Vis (MeOH, $3.6 \times 10^{-4} \mathrm{~mol} \mathrm{dm}^{-3}$ ): $\lambda_{\max }(\log \varepsilon)=522$ (4.54), 491sh (4.48), 338 (4.11), 315 (4.12), $211(4.48) \mathrm{nm}\left(\mathrm{mol}^{-1} \mathrm{dm}^{3} \mathrm{~cm}^{-1}\right)$; UV/Vis (MeCN, $\left.3.1 \times 10^{-4} \mathrm{M}\right): \lambda_{\max }(\log \varepsilon)=526(4.53), 495 \mathrm{sh}(4.45), 336$ (4.11), 316sh (4.08), 212 (4.43) nm $\left(\mathrm{mol}^{-1} \mathrm{dm}^{3} \mathrm{~cm}^{-1}\right)$; CD $\left(\mathrm{MeOH}, 3.6 \times 10^{-4} \mathrm{M}\right): \lambda_{\min / \max }(\Delta \varepsilon)=336(-1.6), 285$ $(-1.5) \mathrm{nm}\left(\operatorname{deg~cm} \mathrm{dmol}^{-1}\right)$; CD $\left(\mathrm{MeCN}, 3.1 \times 10^{-4} \mathrm{M}\right)$ : $\lambda_{\text {min } / \max }(\Delta \varepsilon)=342(-1.7), 277(-1.6) \mathrm{nm}\left(\operatorname{deg~} \mathrm{cm}^{2}\right.$ $\mathrm{dmol}^{-1}$ ); ${ }^{1} \mathrm{H}$ NMR (500 MHz, $\mathrm{CD}_{3} \mathrm{OD}$ ): $\delta=1.71 / 1.79$ (two $\mathrm{s}$, in total $\left.3 \mathrm{H}, \mathrm{H}_{3} \mathrm{C}^{1}\right), 2.14\left(\mathrm{~s}, 3 \mathrm{H}, \mathrm{H}_{3} \mathrm{C} 13^{1}\right), 2.19(\mathrm{~s}, 3 \mathrm{H}$, $\left.\mathrm{H}_{3} \mathrm{C}^{1}\right), 2.22\left(\mathrm{~s}, 3 \mathrm{H}, \mathrm{H}_{3} \mathrm{C} 17^{1}\right), 2.42\left(\mathrm{~m}, 2 \mathrm{H}, \mathrm{H}_{2} \mathrm{C} 12^{2}\right), 2.65$ $\left(\mathrm{m}, 1 \mathrm{H}, \mathrm{H}_{\mathrm{A}} \mathrm{C}^{1}\right), 2.79\left(\mathrm{dd}, J=8.9,14.3 \mathrm{~Hz}, 1 \mathrm{H}, \mathrm{H}_{\mathrm{A}} \mathrm{C} 5\right), 2.84$ $\left(\mathrm{m}, 1 \mathrm{H}, \mathrm{H}_{\mathrm{B}} \mathrm{C} 3^{1}\right), 3.12\left(\mathrm{~m}, 2 \mathrm{H}, \mathrm{H}_{2} \mathrm{C} 12^{1}\right), 3.40(\mathrm{dd}, J=4.6$, $\left.14.3 \mathrm{~Hz}, 1 \mathrm{H}, \mathrm{H}_{\mathrm{A}} \mathrm{C} 5\right), 3.76\left(\mathrm{~s}, 3 \mathrm{H}, \mathrm{H}_{3} \mathrm{C} 8^{5}\right), 3.77(\mathrm{~m}, 1 \mathrm{H}$, $\left.\mathrm{H}_{\mathrm{A}} \mathrm{C}^{2}\right), 3.83\left(\mathrm{~m}, 1 \mathrm{H}, \mathrm{H}_{\mathrm{B}} \mathrm{C}^{2}\right), 4.59(\mathrm{~m}, 1 \mathrm{H}, \mathrm{HC} 4), 5.52(\mathrm{~d}$, $\left.J=11.7 \mathrm{~Hz}, 1 \mathrm{H}, \mathrm{H}_{\mathrm{A}} \mathrm{C} 18^{2}\right), 6.13(\mathrm{~s}, 1 \mathrm{H}, \mathrm{HC} 15), 6.33$ (dd, $\left.J=1.4,17.7 \mathrm{~Hz}, 1 \mathrm{H}, \mathrm{H}_{\mathrm{B}} \mathrm{C} 18^{2}\right), 6.66(\mathrm{dd}, J=11.7,17.7 \mathrm{~Hz}$, $\left.1 \mathrm{H}, \mathrm{HC} 18^{1}\right) \mathrm{ppm} ;{ }^{13} \mathrm{C}$ NMR $\left(125 \mathrm{MHz}, \mathrm{CD}_{3} \mathrm{OD}\right.$, obtained on basis of ${ }^{1} \mathrm{H},{ }^{13} \mathrm{C}-\mathrm{HSQC}$ and ${ }^{1} \mathrm{H},{ }^{13} \mathrm{C}$-HMBC spectra): $\delta=8.1$ $\left(\mathrm{C} 2^{1}\right), 9.0\left(\mathrm{C}^{1} \& \mathrm{C} 17^{1}\right), 9.1\left(\mathrm{C} 13^{1}\right), 24.6\left(\mathrm{C} 12^{1}\right), 29.6(\mathrm{C} 5)$, $30.6\left(\mathrm{C} 3^{1}\right), 38.6\left(\mathrm{C} 12^{2}\right), 52.8\left(\mathrm{C} 8^{5}\right), 60.3(\mathrm{C} 4), 60.9\left(\mathrm{C}^{2}\right)$, $98.8(\mathrm{C} 15), 117.2(\mathrm{C} 7), 121.0\left(\mathrm{C} 18^{2}\right), 126.7\left(\mathrm{C} 18^{1}\right), 128.8$ (C18), 130.6 (C2), 136.8 (C8), 137.9 (C13), 141.2 (C12), 142.1 (C17), 144.8 (C6), 145.7 (C16), 147.1 (C11), 155.8 (C3), 166.4 (C14), 171.2 (C8 $\left.{ }^{3}\right), 172.0$ (C19), 176.1 (C1), $180.9\left(\mathrm{C} 12^{3}\right)$ ppm; ESI-MS (positive mode): $\mathrm{m} / z=1337.1$ $\left(53,[2 \mathrm{M}-2 \mathrm{H}+3 \mathrm{~K}]^{+}\right), 1355.1\left(41,[2 \mathrm{M}-2 \mathrm{H}+\mathrm{Na}+2 \mathrm{~K}]^{+}\right)$, 1334.1 (38), $1333.1\left(46,[2 \mathrm{M}-\mathrm{H}+2 \mathrm{~K}]^{+}\right), 1318.2$ (35), $1317.2\left(50,[2 \mathrm{M}-\mathrm{H}+\mathrm{K}+\mathrm{Na}]^{+}\right), 707.2(40), 706.2(70)$, $705.2\left(82,[\mathrm{M}-\mathrm{H}+2 \mathrm{~K}]^{+}\right), 691.1(25), 690.1(40), 689.1$ $\left(100,[\mathrm{M}-\mathrm{H}+\mathrm{Na}+\mathrm{K}]^{+}\right), 669.1(10), 668.1(25), 667.1(78$, $\left.[\mathrm{M}+\mathrm{K}]^{+}\right), 651.4\left(28,[\mathrm{M}+\mathrm{Na}]^{+}\right)$.

Acknowledgements Open access funding provided by Austrian Science Fund (FWF). We are grateful to the Austrian Science Fund (FWF, Proj. No. P-28522) for financial support.

Open Access This article is distributed under the terms of the Creative Commons Attribution 4.0 International License (http://creativeco mmons.org/licenses/by/4.0/), which permits unrestricted use, distribution, and reproduction in any medium, provided you give appropriate credit to the original author(s) and the source, provide a link to the Creative Commons license, and indicate if changes were made.

\section{References}

1. Hendry GAF, Houghton JD, Brown SB (1987) New Phytol 107:255

2. Kräutler B, Jaun B, Bortlik K, Schellenberg M, Matile P (1991) Angew Chem Int Ed 30:1315 
3. Matile P (1987) Chimia 41:376

4. Kräutler B (2014) Chem Soc Rev 43:6227

5. Kräutler B (2016) Angew Chem Int Ed 55:4882

6. Kräutler B, Hörtensteiner S (2013) Chlorophyll breakdownchemistry, biochemistry and biology. In: Ferreira GC, Kadish KM, Smith KM, Guilard R (eds) Handbook of porphyrin science, vol 28. World Scientific Publishing, Singapore, p 117

7. Hörtensteiner S, Kräutler B (2011) Biochim Biophys Acta - Bioenerg 1807:977

8. Kuai B, Chen J, Hörtensteiner S (2017) J Exp Bot 69:751

9. Kräutler B, Mühlecker W, Anderl M, Gerlach B (1997) Helv Chim Acta 80:1355

10. Engel N, Curty C, Gossauer A (1996) Plant Physiol Biochem 34:77

11. Kräutler B (2019) Synlett 30:263

12. Pružinska A, Tanner G, Anders I, Roca M, Hörtensteiner S (2003) Proc Natl Acad Sci USA 100:15259

13. Hörtensteiner $S$, Wüthrich KL, Matile $P$, Ongania KH, Kräutler B (1998) J Biol Chem 273:15335

14. Pružinska A, Anders I, Aubry S, Schenk N, Tapernoux-Lüthi E, Müller T, Kräutler B, Hörtensteiner S (2007) Plant Cell 19:369

15. Rodoni S, Vicentini F, Schellenberg M, Matile P, Hörtensteiner S (1997) Plant Physiol 115:677

16. Wüthrich KL, Bovet L, Hunziker PE, Donnison IS, Hörtensteiner S (2000) Plant J 21:189

17. Sugishima M, Kitamori Y, Noguchi M, Kohchi T, Fukuyama K (2009) J Mol Biol 389:376

18. Mühlecker W, Ongania KH, Kräutler B, Matile P, Hörtensteiner S (1997) Angew Chem Int Ed 36:401

19. Mühlecker W, Kräutler B, Moser D, Matile P, Hörtensteiner S (2000) Helv Chim Acta 83:278

20. Moser S, Müller T, Ebert M-O, Jockusch S, Turro NJ, Kräutler B (2008) Angew Chem Int Ed 47:8954

21. Erhart T, Mittelberger C, Liu XJ, Podewitz M, Li CJ, Scherzer G, Stoll G, Valls J, Robatscher P, Klaus RL, Oberhuber M, Kräutler B (2018) Chem Eur J 24:17268

22. Oberhuber M, Berghold J, Breuker K, Hörtensteiner S, Kräutler B (2003) Proc Natl Acad Sci USA 100:6910

23. Oberhuber M, Berghold J, Kräutler B (2008) Angew Chem Int Ed 47:3057

24. Christ B, Süssenbacher I, Moser S, Bichsel N, Egert A, Müller T, Kräutler B, Hörtensteiner S (2013) Plant Cell 25:1868
25. Süssenbacher I, Hörtensteiner S, Kräutler B (2015) Angew Chem Int Ed 54:13777

26. Losey FG, Engel N (2001) J Biol Chem 276:8643

27. Christ B, Hörtensteiner S (2014) J Plant Growth Regulation 33:4

28. Roiser M, Müller T, Kräutler B (2015) J Agric Food Chem 63:1385

29. Roca M, Rios JJ, Perez-Galvez A (2018) Phytochem Rev 17:453

30. Moser S, Ulrich M, Müller T, Kräutler B (2008) Photochem Photobiol Sci 7:1577

31. Li CJ, Wurst K, Jockusch S, Gruber K, Podewitz M, Liedl KR, Kräutler B (2016) Angew Chem Int Ed 55:15760

32. Ulrich M, Moser S, Müller T, Kräutler B (2011) Chem Eur J 17:2330

33. Li CJ, Ulrich M, Liu X, Wurst K, Müller T, Kräutler B (2014) Chem Sci 5:3388

34. Li CJ, Erhart T, Liu XJ, Kräutler B (2019) Chem Eur J 25:4052

35. Li CJ, Kräutler B (2015) Dalton Trans 44:10116

36. Li CJ, Kräutler B (2016) J Porphyrins Phthalocyanines 20:388

37. Li CJ, Wurst K, Berghold J, Podewitz M, Liedl KR, Kräutler B (2018) Chem Eur J 24:2987

38. Lightner DA (2013) Bilirubin: Jekyll and Hyde pigment of life. Progress in the chemistry of organic natural products, vol 98. Springer, Vienna, $\mathrm{p} 1$

39. Erhart T, Vergeiner S, Kreutz C, Kräutler B, Müller T (2018) Angew Chem Int Ed 57:14937

40. Hörtensteiner S (2006) Annu Rev Plant Biol 57:55

41. Kräutler B, Matile P (1999) Acc Chem Res 32:35

42. Moser S, Müller T, Oberhuber M, Kräutler B (2009) Eur J Org Chem 2009:21

43. Falk H (1989) Chemistry of linear oligopyrroles and bile pigments. Springer, Wien

44. Burgie ES, Vierstra RD (2014) Plant Cell 26:4568

45. Fushimi K, Ikeuchi M, Narikawa R (2017) Photochem Photobiol 93:903

46. Ma Q, Hua HH, Chen Y, Liu BB, Kramer AL, Scheer H, Zhao KH, Zhou M (2012) FEBS J 279:4095

Publisher's Note Springer Nature remains neutral with regard to jurisdictional claims in published maps and institutional affiliations. 